\title{
Performance of progressive and constant tapered instruments rotary systems at canal preparation
}

Desempenho de sistemas endodônticos rotatórios constante e progressivo no preparo do canal radicular

\author{
Bruna GENARI ${ }^{1}$ \\ (iD) ORCID iD 0000-0002-6329-9543 \\ Ruggiero Silveira STELLO' \\ (iD) ORCID iD 0000-0002-9943-9827 \\ Fabiana Soares GRECCA ${ }^{1}$ \\ (D) ORCID iD 0000-0001-8299-160X \\ Susana Maria Werner SAMUEL ${ }^{1}$ \\ (D) ORCID iD 0000-0001-5467-2636 \\ Fabrício Mezzomo COLLARES 1 \\ (iD) ORCID iD 0000-0002-1382-0150 \\ Paul Michael Howell DUMMER²
}

\section{ABSTRACT}

\section{Objective}

The aim of this study was to compare the performance of two nickel-titanium rotary systems regarding the preparation time, final shape of canal, incidence of aberration, transportation, and fracture of instrument.

\section{Methods}

A total of 40 simulated canals in resin blocks with 300 curves and a length of $17 \mathrm{~mm}$ were divided randomly into two groups: preparation with ProTaper and BioRaCe systems up to F5 and BR5 respectively. Pre- and post-operative canal images were taken and superimposed in order to identify aberrations, transportation, and to take measurements of the canal width. In addition, the preparation time and instrument fractures were recorded. The data were analyzed using Student's t test.

\section{Results}

There is no difference ( $p>$.05) comparing the systems regarding preparation time, canal aberration, and instrument fracture rates. The progressive tapered instruments of ProTaper prepared significantly larger canal widths in the apical third $(p<.05)$.

\section{Conclusion}

Overall, both systems provided safe canal preparation, associated with few canal aberrations and instrument fractures.

Indexing terms: Dental pulp cavity. Endodontics. In vitro techniques.

\section{RESUMO}

\section{Objetivo}

Comparar o desempenho de dois sistemas rotatórios em relação ao tempo de preparo, formato final e alterações do canal, desvio e fratura de instrumento.

\section{Métodos}

Um total de 40 canais simulados em blocos de resina com curvatura de 30 o e comprimento de 17 mm foram divididos randomicamente nos sistemas ProTaper e BioRaCe preparados até F5 e BR5 respectivamente. Imagens pré e após o preparo dos canais foram obtidas e superpostas para identificação de alterações de forma, desvios e largura. O tempo de preparo e fratura de instrumentos também foram avaliados. Os dados foram analisados por teste $t$ de Student.

\section{Resultados}

O tempo de preparo, alterações de forma e taxa de fratura de instrumentos não teve diferença entre os dois sistemas avaliados ( $p>0,05)$. Os instrumentos progressivos do ProTaper resultou em canais significativamente mais largos no terço apical $(p<0,05)$.

\section{Conclusão}

Os dois sistemas rotatórios avaliados resultaram em preparo endodôntico seguro, com poucas alterações e fratura de instrumento.

Termos de indexação: Cavidade pulpar. Endodontia. Preparo endodôntico.

\footnotetext{
${ }^{1}$ Universidade Federal do Rio Grande do Sul, Faculdade de Odontologia. Rua Ramiro Barcelos, 2492, 33085-003, Porto Alegre, RS, Brasil. Correspondência para / Correspondence to: FM COLLARES. E-mail: <fabricio.collares@ufrgs.br>

${ }^{2}$ School of Dentistry, Cardiff University, Cardiff, Wales, United Kingdom.

$\boldsymbol{\nabla} \boldsymbol{\nabla} \boldsymbol{\nabla}$

Como citar este artigo / How to cite this article

Genar B, Stello RS, Grecca FS, Samuel SMW, Collares FM, Dummer PMH. Performance of progressive and constant tapered instruments rotary systems at canal preparation. RGO, Rev Gaúch Odontol. 2018;66(3):225-231. http://dx.doi.org/10.1590/1981-863720180003000053366
} 


\section{INTRODUCTION}

The great variation in teeth anatomy could complicate the shaping and disinfection in the root canal preparation and lead to deviations and aberrations $[1,2]$. The difficulty of enlarging curved canals led to the development of instruments [1], such as nickel-titanium (NiTi) rotary instruments which present super elasticity [3-5]. The instruments of the systems have difference in the design - taper, blade, tip - which could influence the final shape of the root canal, preparation time, incidence of aberrations, and transportation [6,7].

The ProTaper instruments present a convex triangular cross-sectional design, a progressive taper, and a non-cutting tip. Despite also having the triangular cross-sectional design and non-cutting tip, the BioRaCe instruments present a constant taper and alternating cutting edge. These systems present a difference in taper design (progressive and constant) that could influence the final shape of the canal and preparation time $[7,8]$.

Therefore, the aim of this study was to compare two (NiTi) rotary systems regarding the preparation time, final shape of canal, incidence of aberration, transportation, and fracture of instrument. The null hypothesis tested is that there is no difference between progressive and constant tapered designs.

\section{METHODS}

A total of 40 simulated canals in resin blocks (Endo-Blocks, Dentsply Maillefer, Ballaigues, Vaud, Switzerland) with 300 curves and a length of $17 \mathrm{~mm}$ were used. Canals were photographed to show their full curvature. Using a camera (Panasonic F10 CCD, Panasonic, Lake Forest, California, USA) with a film focus distance of $32 \mathrm{~cm}$, the images were obtained and stored in Image Pro Plus software (Media Cybernetics,
Bethesda, Maryland, USA). The simulated canals were divided randomly into two groups of 20 specimens. Each group was prepared using a different instrument system.

\section{Preparation of canals}

Two nickel-titanium instrument systems, ProTaper Universal (Dentsply Maillefer, Ballaigues, Vaud, Switzerland) and BioRaCe (FKG Dentaire, La Chaux-deFonds, Neuchatel, Switzerland) were used in a crowndown preparation technique. Each instrument was used to enlarge four canals. If the instruments fractured, they were replaced. The instruments were powered by a hand-piece and an electric motor (X-SmartTM, Dentsply Maillefer, Ballaigues, Vaud, Switzerland). The ProTaper system was used at a speed of $250 \mathrm{rpm}$ and a torque control level of $1 \mathrm{Nm}$, while for the BioRaCe instruments, the rotational speed was set to $500 \mathrm{rpm}$ and a torque control level of $1 \mathrm{Nm}$, based on the manufacturers' instructions.

All canals were instrumented to a working length of $16 \mathrm{~mm}$ and the first instrument used in preparation was size $10 \mathrm{~K}$-file. The ProTaper instruments sequence was S1, S2, and SX until two-thirds of working length and S1, S2, F1, F2, F3, F4, and F5 to working length. For the BioRaCe system, the instrumentation sequence was BR0, BR1, BR2, BR3, BR4, and BR5. Both systems were used based on the manufacturers' instructions. A lubricant for root canals (Glyde, Dentsply Maillefer, Ballaigues, Vaud, Switzerland) was placed on each instrument prior to use. Between each instrument, the canals were irrigated with $0.5 \mathrm{~mL}$ of distilled water, and the working length was recapitulated with a size $10 \mathrm{~K}$-file. A single operator trained to use both systems prepared all canals. Although the instruments have different diameters and tapers (Table 1), the ProTaper and BioRaCe systems were used up to F5 and BR5 respectively to study their performance.

Table 1. The instruments' sequence, their diameter and taper for each system.

\begin{tabular}{|c|c|c|c|c|c|c|c|}
\hline \multicolumn{4}{|c|}{ ProTaper } & \multicolumn{4}{|c|}{ BioRaCe } \\
\hline Sequence & $\begin{array}{l}\text { Working length } \\
(\mathrm{mm})\end{array}$ & Diameter & Taper & Sequence & $\begin{array}{c}\text { Working } \\
\text { length (mm) }\end{array}$ & Diameter & Taper \\
\hline F2 & 16 & 25 & .08 & BR2 & 16 & 25 & .04 \\
\hline F3 & 16 & 30 & .09 & BR3 & 16 & 25 & .06 \\
\hline F5 & 16 & 50 & .05 & BR5 & 16 & 40 & .04 \\
\hline
\end{tabular}




\section{Preparation time}

The time required to prepare the simulated canals was measured in seconds; the time required to change instruments, to use lubricant, and to irrigate was not included. The total preparation time included the F1, F2, F3, F4 and F5 instruments for the ProTaper system, and BR1, BR2, BR3, BR4 and BR5 for BioRaCe. The time using S1, S2 and SX and BRO instruments were discarded to be possible to compare both systems with the same number of used instruments. The mean of the preparation time per instrument was also calculated.

\section{Canal widths}

The post-operative widths were measured for each millimeter of the canals. Adobe Photoshop software (Adobe Systems, San Jose, California, USA) was used to make these measurements. A single operator trained to use the program analyzed all images.

\section{Canal aberrations}

Pre-operatively, and after using each instrument, an image of each canal was obtained. The pre- and postoperative images were superimposed in order to identify the presence of aberrations, including zips/elbows, danger zones, ledges, and perforations [2]. The presence of canal transportation was recorded. A single blinded investigator conducted the evaluations.

\section{Instrument fracture}

The instruments were visually evaluated after each use. If a deformation or fracture was detected, the instrument was replaced, and the occurrence was recorded.

\section{Data analysis}

Student's t test was used to analyze preparation time, canal widths, instrument fracture, and canal aberration comparing ProTaper and BioRaCe. SPSS 17.0 (SPSS Inc., Chicago, Illinois, USA) was used at a significance level of .05.

\section{RESULTS}

\section{Preparation time}

The mean of preparation time per instrument was $7.6( \pm 3.0)$ seconds for the ProTaper system and 7.9 $( \pm 3.2)$ seconds for the BioRaCe system. The mean of the total preparation time was $38.2( \pm 4.0)$ seconds for ProTaper and $40.8( \pm 5.9)$ for BioRaCe. There was no significant difference between the systems ( $p>.05)$.

\section{Canal widths}

The results for canal widths are presented in Figures 1 and 2 and Table 2. Comparing the ProTaper and BioRaCe systems, the F1 prepared significantly larger canals than BR1. The F2 prepared larger canal widths than BR2 and F3 larger than BR3, except at 1 $\mathrm{mm}$ from the apex. The F4 prepared significantly larger canals than BR4, except at apical third (at 1, 2, and 3 $\mathrm{mm}$ from the apex) and the $\mathrm{F} 5$ prepared larger canals than BR5, except at 2, 3 and $4 \mathrm{~mm}$ from the apex.

Table 2. Comparison of canal widths ( $\mathrm{mm}$ ) obtained with ProTaper and BioRaCe instruments at different distances from the apex.

\begin{tabular}{|c|c|c|c|c|c|c|c|c|c|c|c|c|c|}
\hline & $1 \mathrm{~mm}$ & $2 \mathrm{~mm}$ & $3 \mathrm{~mm}$ & $4 \mathrm{~mm}$ & $5 \mathrm{~mm}$ & $6 \mathrm{~mm}$ & $7 \mathrm{~mm}$ & $8 \mathrm{~mm}$ & $9 \mathrm{~mm}$ & $10 \mathrm{~mm}$ & 11 mm & $12 \mathrm{~mm}$ & 13 mm \\
\hline F5 & $\begin{array}{c}0.484 \\
( \pm 0.047) A\end{array}$ & $\begin{array}{c}0.682 \\
( \pm 0.043) \\
A\end{array}$ & $\begin{array}{c}0.735 \\
( \pm 0.028) A\end{array}$ & $\begin{array}{c}0.752 \\
( \pm 0.038) A\end{array}$ & $\begin{array}{c}0.764 \\
( \pm 0.034) \\
A\end{array}$ & $\begin{array}{c}0.78 \\
( \pm 0.039) \mathrm{A}\end{array}$ & $\begin{array}{c}0.817 \\
( \pm 0.024) A\end{array}$ & $\begin{array}{c}0.854 \\
( \pm 0.024) A\end{array}$ & $\begin{array}{c}0.901 \\
( \pm 0.017) \mathrm{A}\end{array}$ & $\begin{array}{c}0.954 \\
( \pm 0.037) A\end{array}$ & $\begin{array}{c}1.145 \\
( \pm 0.075) \mathrm{A}\end{array}$ & $\begin{array}{c}1.429 \\
( \pm 0.087) A\end{array}$ & $\begin{array}{c}1.822 \\
( \pm 0.15) \mathrm{A}\end{array}$ \\
\hline BR5 & $\begin{array}{c}0.442 \\
( \pm 0.034) \mathrm{B}\end{array}$ & $\begin{array}{c}0.669 \\
( \pm 0.046) \\
A\end{array}$ & $\begin{array}{c}0.724 \\
( \pm 0.044) \mathrm{A}\end{array}$ & $\begin{array}{c}0.734 \\
( \pm 0.03) \mathrm{A}\end{array}$ & $\begin{array}{c}0.741 \\
( \pm 0.03) \mathrm{B}\end{array}$ & $\begin{array}{c}0.744 \\
( \pm 0.021) \mathrm{B}\end{array}$ & $\begin{array}{c}0.759 \\
( \pm 0.023) \mathrm{B}\end{array}$ & $\begin{array}{c}0.804 \\
( \pm 0.028) \mathrm{B}\end{array}$ & $\begin{array}{c}0.838 \\
( \pm 0.037) \mathrm{B}\end{array}$ & $\begin{array}{c}0.909 \\
( \pm 0.026) \mathrm{B}\end{array}$ & $\begin{array}{c}0.963 \\
( \pm 0.046) \mathrm{B}\end{array}$ & $\begin{array}{c}1.072 \\
( \pm 0.102) \mathrm{B}\end{array}$ & $\begin{array}{c}1.424 \\
( \pm 0.019) \mathrm{B}\end{array}$ \\
\hline F4 & $\begin{array}{c}0.403 \\
( \pm 0.057) \mathrm{A}\end{array}$ & $\begin{array}{c}0.532 \\
( \pm 0.033) \\
A\end{array}$ & $\begin{array}{c}0.593 \\
( \pm 0.022) A\end{array}$ & $\begin{array}{c}0.652 \\
( \pm 0.031) A\end{array}$ & $\begin{array}{c}0.688 \\
( \pm 0.031) \\
A\end{array}$ & $\begin{array}{c}0.749 \\
( \pm 0.026) \mathrm{A}\end{array}$ & $\begin{array}{c}0.8 \\
( \pm 0.027) \mathrm{A}\end{array}$ & $\begin{array}{c}0.843 \\
( \pm 0.025) A\end{array}$ & $\begin{array}{c}0.893 \\
( \pm 0.022) \mathrm{A}\end{array}$ & $\begin{array}{c}0.939 \\
( \pm 0.034) \mathrm{A}\end{array}$ & $\begin{array}{c}1.094 \\
( \pm 0.073) \mathrm{A}\end{array}$ & $\begin{array}{c}1.371 \\
( \pm 0.128) A\end{array}$ & $\begin{array}{c}1.755 \\
( \pm 0.166) A\end{array}$ \\
\hline BR4 & $\begin{array}{c}0.416 \\
( \pm 0.045) \mathrm{A}\end{array}$ & $\begin{array}{c}0.529 \\
( \pm 0.044) \\
A\end{array}$ & $\begin{array}{c}0.577 \\
( \pm 0.039) A\end{array}$ & $\begin{array}{c}0.597 \\
( \pm 0.035) \mathrm{B}\end{array}$ & $\begin{array}{c}0.639 \\
( \pm 0.021) \\
B\end{array}$ & $\begin{array}{c}0.671 \\
( \pm 0.026) \mathrm{B}\end{array}$ & $\begin{array}{c}0.71 \\
( \pm 0.017) \mathrm{B}\end{array}$ & $\begin{array}{c}0.761 \\
( \pm 0.024) \mathrm{B}\end{array}$ & $\begin{array}{c}0.806 \\
( \pm 0.024) \mathrm{B}\end{array}$ & $\begin{array}{c}0.897 \\
( \pm 0.026) \mathrm{B}\end{array}$ & $\begin{array}{c}0.948 \\
( \pm 0.034) \mathrm{B}\end{array}$ & $\begin{array}{c}1.055 \\
( \pm 0.094) \mathrm{B}\end{array}$ & $\begin{array}{c}1.386 \\
( \pm 0.187) \mathrm{B}\end{array}$ \\
\hline F3 & $\begin{array}{c}0.353 \\
( \pm 0.043) A\end{array}$ & $\begin{array}{c}0.442 \\
( \pm 0.033) \\
A\end{array}$ & $\begin{array}{c}0.543 \\
( \pm 0.039) A\end{array}$ & $\begin{array}{c}0.617 \\
( \pm 0.031) A\end{array}$ & $\begin{array}{c}0.665 \\
( \pm 0.031) \\
A\end{array}$ & $\begin{array}{c}0.718 \\
( \pm 0.024) A\end{array}$ & $\begin{array}{c}0.763 \\
( \pm 0.019) A\end{array}$ & $\begin{array}{c}0.809 \\
( \pm 0.032) \mathrm{A}\end{array}$ & $\begin{array}{c}0.875 \\
( \pm 0.025) A\end{array}$ & $\begin{array}{c}0.927 \\
( \pm 0.03) A\end{array}$ & $\begin{array}{c}1.068 \\
( \pm 0.079) \mathrm{A}\end{array}$ & $\begin{array}{c}1.317 \\
( \pm 0.101) A\end{array}$ & $\begin{array}{c}1.655 \\
( \pm 0.148) A\end{array}$ \\
\hline BR3 & $\begin{array}{c}0.368 \\
( \pm 0.042) A\end{array}$ & $\begin{array}{c}0.401 \\
( \pm 0.031) \\
B\end{array}$ & $\begin{array}{c}0.469 \\
( \pm 0.04) \mathrm{B}\end{array}$ & $\begin{array}{c}0.526 \\
( \pm 0.034) \mathrm{B}\end{array}$ & $\begin{array}{c}0.584 \\
( \pm 0.027) \\
B\end{array}$ & $\begin{array}{c}0.649 \\
( \pm 0.028) \mathrm{B}\end{array}$ & $\begin{array}{c}0.71 \\
( \pm 0.02) \mathrm{B}\end{array}$ & $\begin{array}{c}0.768 \\
( \pm 0.028) \mathrm{B}\end{array}$ & $\begin{array}{c}0.815 \\
( \pm 0.033) \mathrm{B}\end{array}$ & $\begin{array}{c}0.905 \\
( \pm 0.029) \mathrm{B}\end{array}$ & $\begin{array}{c}0.943 \\
( \pm 0.028) \mathrm{B}\end{array}$ & $\begin{array}{c}1.055 \\
( \pm 0.05) \mathrm{B}\end{array}$ & $\begin{array}{c}1.422 \\
( \pm 0.157) \mathrm{B}\end{array}$ \\
\hline
\end{tabular}




\begin{tabular}{|c|c|c|c|c|c|c|c|c|c|c|c|c|c|}
\hline F2 & $\begin{array}{c}0.311 \\
( \pm 0.041) \mathrm{A}\end{array}$ & $\begin{array}{c}0.384 \\
( \pm 0.032) \\
A\end{array}$ & $\begin{array}{c}0.476 \\
( \pm 0.035) \mathrm{A}\end{array}$ & $\begin{array}{c}0.539 \\
( \pm 0.03) \mathrm{A}\end{array}$ & $\begin{array}{c}0.59 \\
( \pm 0.02) \mathrm{A}\end{array}$ & $\begin{array}{c}0.645 \\
( \pm 0.027) \mathrm{A}\end{array}$ & $\begin{array}{c}0.718 \\
( \pm 0.027) \mathrm{A}\end{array}$ & $\begin{array}{c}0.769 \\
( \pm 0.03) \mathrm{A}\end{array}$ & $\begin{array}{c}0.83 \\
( \pm 0.030) \mathrm{A}\end{array}$ & $\begin{array}{c}0.906 \\
( \pm 0.047) \mathrm{A}\end{array}$ & $\begin{array}{c}1.078 \\
( \pm 0.078) \mathrm{A}\end{array}$ & $\begin{array}{c}1.327 \\
( \pm 0.102) \mathrm{A}\end{array}$ & $\begin{array}{c}1.672 \\
( \pm 0.135) \mathrm{A}\end{array}$ \\
\hline BR2 & $\begin{array}{c}0.318 \\
( \pm 0.03) \mathrm{A}\end{array}$ & $\begin{array}{c}0.352 \\
( \pm 0.02) \mathrm{B}\end{array}$ & $\begin{array}{c}0.411 \\
( \pm 0.025) \mathrm{B}\end{array}$ & $\begin{array}{c}0.447 \\
( \pm 0.026) \mathrm{B}\end{array}$ & $\begin{array}{c}0.501 \\
( \pm 0.015) \\
B\end{array}$ & $\begin{array}{c}0.538 \\
( \pm 0.027) \mathrm{B}\end{array}$ & $\begin{array}{c}0.598 \\
( \pm 0.021) \mathrm{B}\end{array}$ & $\begin{array}{c}0.618 \\
( \pm 0.020) \mathrm{B}\end{array}$ & $\begin{array}{c}0.647 \\
( \pm 0.034) \mathrm{B}\end{array}$ & $\begin{array}{c}0.717 \\
( \pm 0.024) \mathrm{B}\end{array}$ & $\begin{array}{c}0.77 \\
( \pm 0.05) \mathrm{B}\end{array}$ & $\begin{array}{c}0.978 \\
( \pm 0.199) \mathrm{B}\end{array}$ & $\begin{array}{c}1.437 \\
( \pm 0.291) \mathrm{B}\end{array}$ \\
\hline F1 & $\begin{array}{c}0.307 \\
( \pm 0.039) \mathrm{A}\end{array}$ & $\begin{array}{c}0.354 \\
( \pm 0.029) \\
A\end{array}$ & $\begin{array}{c}0.427 \\
( \pm 0.036) \mathrm{A}\end{array}$ & $\begin{array}{c}0.489 \\
( \pm 0.035) \mathrm{A}\end{array}$ & $\begin{array}{c}0.558 \\
( \pm 0.027) \\
A\end{array}$ & $\begin{array}{c}0.619 \\
( \pm 0.031) \mathrm{A}\end{array}$ & $\begin{array}{c}0.685 \\
( \pm 0.026) A\end{array}$ & $\begin{array}{c}0.742 \\
( \pm 0.025) \mathrm{A}\end{array}$ & $\begin{array}{c}0.804 \\
( \pm 0.033) \mathrm{A}\end{array}$ & $\begin{array}{c}0.933 \\
( \pm 0.099) \mathrm{A}\end{array}$ & $\begin{array}{c}1.087 \\
( \pm 0.124) \mathrm{A}\end{array}$ & $\begin{array}{c}1.323 \\
( \pm 0.176) \mathrm{A}\end{array}$ & $\begin{array}{c}1.646 \\
( \pm 0.197) \mathrm{A}\end{array}$ \\
\hline
\end{tabular}

*t-test. Significance level of 0.05 .

Capitalized letters represent comparisons in the columns between the instruments of both systems. Different letters represent significantly difference $(p<.05)$.

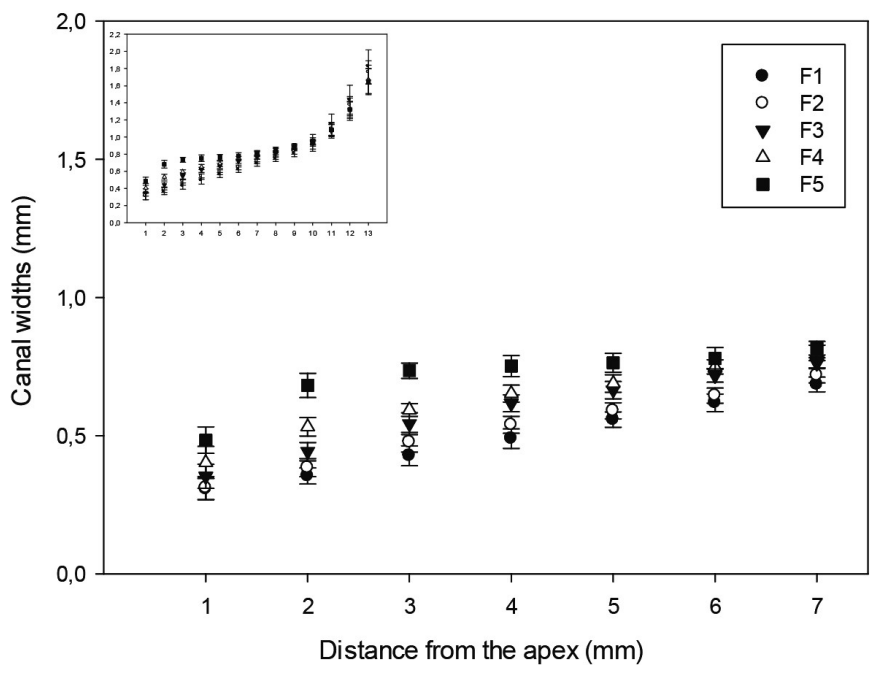

Figure 1. Canal widths prepared with ProTaper instruments

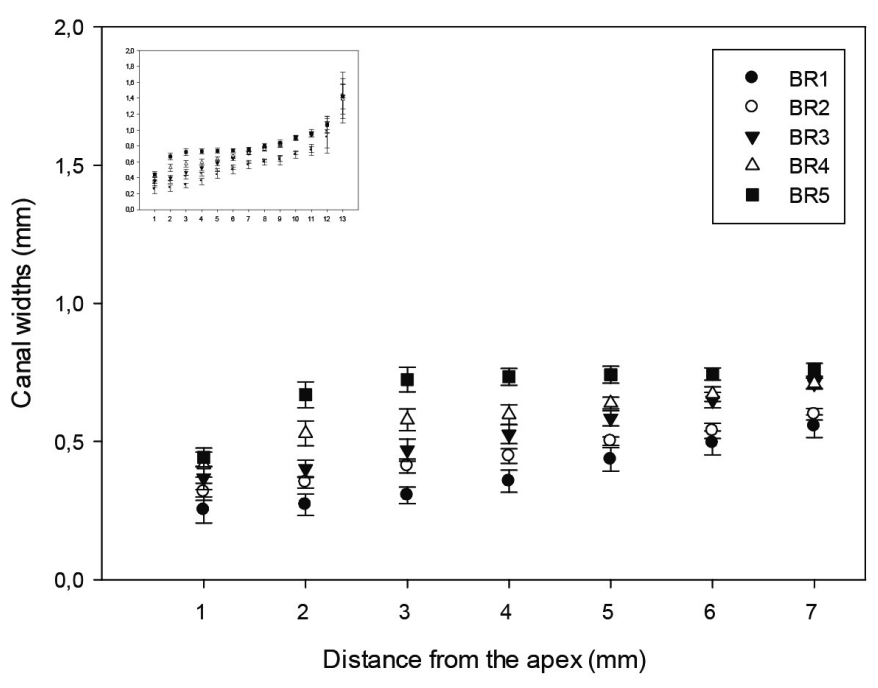

Figure 2. Canal widths prepared with BioRaCe instruments.

\section{Canal aberrations}

No statistically significant differences ( $p>.05)$ regarding aberrations were found between the ProTaper and BioRaCe systems. With the ProTaper instruments, the F3 instrument caused one ledge in the middle third and one zip was produced by the F5 in the apical third. During enlargement with a BR1 instrument, a ledge occurred in the middle third of the canal. One canal of each system was discarded due to aberrations. Transportation was observed in all prepared canals.

\section{Instrument fracture}

One ProTaper instrument (F3) and one BioRaCe (BR1) fractured; there was no significant difference between the instrument systems ( $p>05)$. The BR1 instrument fractured at third use and the $\mathrm{F} 3$ at the second canal preparation. These instruments fractured when the canal aberrations occurred.

\section{DISCUSSION}

The use of rotary systems with different taper did not influence the preparation time and incidence of aberrations, transportation, and fracture of instrument. However, a larger canal diameter in the middle and coronal thirds was obtained with progressive tapered instruments. Therefore, the null hypothesis tested is rejected.

One of the advantages of rotary instruments is their effectiveness in preparing larger canals in a shorter amount of time [5]. Regarding total preparation time, in the present study, there was no significant difference between progressive tapered instruments and constant tapered instruments, contradicting a previous study wherein a progressive tapered system was faster than a constant tapered system [7]. However, the constant tapered system used in that study was different than the constant system used in the present study. Few studies presented the preparation times for rotary systems [5,9], ranging from 46 to 152 seconds depending on the 
anatomy of teeth and the number of used instruments. Considering the fact that simulated canals were used in this study and the variation in clinical situation, the preparation time achieved was clinically reliable. However, even with an acceptable preparation time, these instruments should promote a large enough canal width and avoid canal aberrations and instrument fractures to be clinically usable.

The enlargement is associated with the ability to remove infected contents aiding the decontamination procedures of the root canal [10]. The first three ProTaper instruments were not enough to fully instrument under incisors, requiring the F4 and F5 instruments [11]. Considering the mandibular first molar, in the apical third of the mesial root, the widths were up to $0.44 \mathrm{~mm}$ and in the apical third of the distal root, up to $0.48 \mathrm{~mm}$. At 5 and $6 \mathrm{~mm}$ from the apex, the widths of the distal canals were up to $1.34 \mathrm{~mm}$ [12]. It would support an apical working width of at least an ISO size 40 (diameter of $0.4 \mathrm{~mm}$ ) to adequaly clean the apical third of the distal canals of the mandibular first molar [12]. In the present study, it correspondes to F4, F5 or BR5. Generally, the progressive tapered instruments of ProTaper prepared larger canal widths than constant tapered instruments of BioRaCe. A previous study comparing the different taper of instruments showed no significant difference between both systems regarding dentinal tissue removal, but a different constant taper system was used [8]. An increased canal enlargement provides higher decontamination [10], however as the enlargement increases, a higher incidence of aberration could be expected.

Canal aberration is related to the final canal shape [13], which could lead to perforation or incomplete obturation. In the present study, the F5 instrument caused just one zip in the apical third, the F3 caused one ledge in the middle third and BR1 caused a ledge in the middle third. In the present and previous studies, the ProTaper and BioRaCe systems showed no difference regarding canal aberrations [14]. Canal aberration can be related to instrument design [13], increasing when instruments with an active cutting tip are used [15]. In the present study, the instruments have a non-active cutting tip, which could explain the results. Besides the design of the instrument, the risk of aberration can be increased by canal transportation [16]. In the present study, canal transportation was observed with both systems. Comparing both systems, progressive tapered instruments produced more pronounced canal transportation in the apical and middle thirds than constant tapered instruments elsewhere $[8,14,17]$. However, despite the presence of canal transportation, the results of the present study indicated few aberrations with both systems. The occurrence of canal aberrations and instrument fractures did not increase using up to F5 and BR5 instruments.

Instrument fracture is a concern at canal enlargement and it is associated with the safe use of the rotary instruments [16]. Both systems presented instrument fracture in this study-one F3 instrument and one BR1. The fractured instruments in the present study were the same ones that produced aberrations. The B1 instrument fracture occurred at third use and the F3 at the second canal preparation without visual deformation. Instrument fracture often occurs clinically without plastic deformation [18] when they are subjected to cyclic fatigue stresses $[19,20]$. Previous studies observed that the F3 instruments are very susceptible to cyclic fatigue $[21,22]$. The angle and radius of canal curvature, and the increased diameter and taper of the instruments affected the instruments' susceptibility to cyclic fatigue $[19,20,23]$. Although an increase in instrument size could decrease the resistance to cyclic fatigue $[20,22,24]$, in the present study the instruments with largest diameter of the systems did not suffer fracture.

Simulated canals have been used in several studies $[4,13,14,15,17,21,25]$ and they allow test the instruments performance under standardized condition, indicating the instrument potential 11. All instruments of the systems were tested to know the instruments performance in laboratorial conditions.

\section{CONCLUSION}

Within the methodology and results of the present study, it is possible to conclude that progressive tapered instruments prepared larger canal widths and there is no difference regarding preparation time, canal aberration and fracture of instruments between both systems. Overall, both systems provided safe canal preparation, associated with few canal aberrations and instrument fractures.

\section{ACKNOWLEDGEMENTS}

B GENARI and RS STELLO, substantial contributions to the conception and design of the work, the acquisition, analysis and interpretation of data for the work; drafting the work; agreement to be accountable for all aspects of the work in ensuring that questions 
related to the accuracy or integrity of any part of the work are appropriately investigated and resolved. FS GRECCA, SMW SAMUEL, FM COLLARES and PMH DUMMER, substantial contributions to the conception and design of the work, the acquisition, analysis and interpretation of data for the work; revising the draft of the work critically for important intellectual content; agreement to be accountable for all aspects of the work in ensuring that questions related to the accuracy or integrity of any part

\section{REFERENCES}

1. Hülsmann M, Peters OA, Dummer PMH. Mechanical preparation of root: shaping goals, techniques and means. Endod Topics. 2005;10:30-76. doi: 10.1111/j.1601-1546.2005.00152.x

2. Wildey $W L$, Senia S. A new root canal instrument and instrumentation technique: A preliminary report. Oral Surg Oral Med Oral Pathol. 1989;67(2):198-207.

3. Sattapan B, Nervo GJ, Palamara JE, Messer HH. Defects in rotary nickel-titanium files after clinical use. J Endod. 2000;26(3):1615. doi: 10.1097/00004770-200003000-00008

4. Debelian G, Trope M. BioRaCe-efficient, safe and biological based sequence files. Roots. 2008;1:20-6.

5. Fariniuk LF, Baratto-Filho F, Guerisoli DMZ, Barbizam JVB, Pécora JD, Sousa-Neto MD. Modeling capacity of ENDOflash files in simulated root canals. Braz Dent J. 2001;12(1):39-42.

6. Guelzow A, Stamm O, Martus P, Kielbassa AM. Comparative study of six rotary nickel-titanium systems and hand instrumentation for root canal preparation. Int Endod J. 2005;38(10):743-52. doi: 10.1111/j.1365-2591.2005.01010.x

7. Veltri M, Mollo A, Mantovani L, Pini P, Balleri P, Grandini S. A comparative study of Endoflare-Hero Shaper and Mtwo NiTi instruments in the preparation of curved root canals. Int Endod J. 2005;38(9):610-6. doi: 10.1111/j.1365-2591.2005.00989.x

8. Veltri M, Mollo A, Pini PP, Ghelli LF, Balleri P. In vitro comparison of shaping abilities of protaper and gt rotary files. J Endod. 2004;30(3):163-6. doi: 10.1097/00004770-200403000-00009

9. Bergmans L, Van Cleynenbreugel J, Beullens M, Wevers $M$, Van Meerbeek B, Lambrechts P. Progressive versus constant tapered shaft design using NiTi rotary instruments. Int Endod J. 2003;36:288-95. doi: 10.1046/j.1365-2591.2003.00650.x

10. You SY, Bae KS, Baek SH, Kum KY, Shon WJ, Lee WC. Lifespan of one nickel-titanium rotary file with reciprocating motion in curved root canals. J Endod. 2010;36:1991-4. doi: 10.1016/j. joen.2010.08.040

11. Mickel AK, Chogle S, Liddle J, Huffaker K, Jones JJ. The role of apical size determination and enlargement in the reduction of intracanal bacteria. J Endod. 2007;33(7):21-3. doi: 10.1016/ S0099-2399(06)81699-7

12. Baratto-Filho F, Vanni JR, Maia SMAS, Souza Neto MD, Leonardi of the work are appropriately investigated and resolved.

\section{Collaborators}

MLBB MEDEIROS, LL MENDES and SLP LOPES, data collect. EL ARAÚJO, sample selection and recruitment. ICG MENDONÇA, spelling review. EN MEDEIROS, data tabulation. TC CAVALCANTI, statistical analysis. NB SANTOS, leader.

DP. [Shaping ability of ProTaper instruments in flattened root canals]. Perspect Oral Sci. 2009;1:25-9.

13. Harris SP, Bowles WR, Fok A, McClanahan SB. An anatomic investigation of the mandibular first molar using microcomputed tomography. J Endod. 2013;39(11):1374-8. doi: 10.1016/j.joen.2013.06.034

14. Yun H, Kim SK. Comparison of the shaping abilities of 4 nickeltitanium rotary instruments in simulated root canals. Oral Surg Oral Med Oral Pathol Oral Radiol Endod. 2003;95(2):228-33. doi: 10.1067/moe.2003.92

15. Bonaccorso A, Cantatore G, Condorelli GG, Schäfer E, Tripi TR. shaping ability of four nickel-titanium rotary instruments in simulated s-shapes canals. J Endod. 2009;35(6):883-6. doi: 10.1016/j.joen.2009.03.007

16. Thompson SA, Dummer PMH. Shaping ability of Quantec Series 2000 rotary nickel-titanium instruments in simulated root canals: Part 2. Int Endod J. 1998;31(4):268-74. doi: 10.1046/j.13652591.1998.00152.x

17. Vaudt J, Bitter K, Kielbassa AM. Evaluation of rotary root canal instruments in vitro: a review. ENDO. 2007;1:189-203.

18. Yang GB, Zhou XD, Zhang $H$, Wu HK. Shaping ability of progressive versus constant taper instruments in simulated root canals. Int Endod J. 2006;39(10):791-9. doi: 10.1111/j.13652591.2006.01151.x

19. Spanaki-Voreadi AP, Kerezoudis NP, Zinelis S. Failure mechanism of ProTaper $\mathrm{Ni}-\mathrm{Ti}$ rotary instruments during clinical use: fractographic analysis. Int Endod J. 2006;39(3):171-8. doi: 10.1111/j.1365-2591.2006.01065.x

20. Pruett JP, Clement DJ, Carnes Jr. DL. Cyclic fatigue testing of nickel-titanium endodontic instruments. J Endod. 1997;23(2):7785. doi: /10.1016/S0099-2399(97)80250-6

21. Calberson FLG, Deroose CAJG, Hommez GMG, De Moor RJG. Shaping ability of ProTaper nickel-titanium files in simulated resin root canals. Int Endod J. 2004;37(9):613-23. doi: 10.1111/j.1365-2591.2004.00860.x

22. Ounsi HF, Salameh Z, Al-Shalan T, Ferrari M, Grandini S, Pashley $\mathrm{DH}$, et al. Effect of clinical use on the cyclic fatigue resistance of ProTaper nickel-titanium rotary instruments. J Endod. 2007;33(6):737-41. doi: 10.1016/j.joen.2007.03.006

23. Luebke NH, Brantley WA. Torsional and metallurgical properties of rotary endodontic instruments. 2. Stainless steel Gates 
Glidden drills. J Endod. 1991;17:319-23. doi: 10.1016/S00992399(06)81699-7

24. Ullmann CJ, Peters OA. Effect of cyclic fatigue on static fracture loads in protaper nickel-titanium rotary instruments. J Endod. 2005;31(3):183-6. doi: 10.1097/01. don.0000137641.87125.8f

25 Merrett SJ, Bryant ST, Dummer PM. Comparison of the shaping ability of RaCe and FlexMaster rotary nickel-titanium systems in simulated canals. J Endod. 2006;32(10):960-2. doi: 10.1016/j. joen.2006.03.002

Received on: $X X / X / X X X X$ Final version resubmitted on: $X X X X X X X X$ Approved on: $X X|X| X X X X$ 